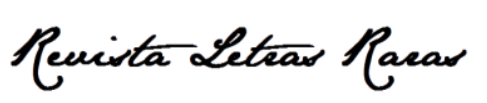

ISSN: 2317-2347 - v. 9, n. 4 (2020)

Todo o conteúdo da RLR está licenciado sob Creative Commons Atribuição 4.0 Internacional

\title{
O Expresso Líbano-Detroit 1
}

\section{Priscila Campolina de Sá Campello *}

Priscila Campello é formada em Letras - habilitação Inglês pela UFMG. Possui mestrado em Literaturas de Língua Inglesa e doutorado em Literatura Comparada também pela FALE-UFMG e realizou o doutorado sanduíche na Universidade da Carolina do Norte em Chapel Hill (EUA). Atualmente é professora adjunta de literaturas em língua inglesa desde 2001 no Curso de Letras da PUC Minas e professora do Programa de Pós-graduação em Letras na mesma instituição. Desenvolve pesquisa na área de literatura de autoria feminina e literaturas de imigrantes nos Estados Unidos.

iD https://orcid.org/0000-0001-8113-4606

\section{Thomaz de Oliveira Gomes *}

Graduando em Letras pela Pontifícia Universidade Católica de Minas Gerais. Tem experiência nas áreas de Revisão e de Tradução, com ênfase em Revisão e Tradução Literárias.

iD https://orcid.org/0000-0002-1031-771X

Recebido: 24 jun. 2020. Aprovado: 01 out. 2020.

Como citar esta tradução:

CAMPELLO, Priscila Campolina de Sá. S. GOMES, Thomaz de Oliveira. O Expresso Líbano-Detroit. Revista Letras Raras, Campina Grande, v. 9, n. 4, p. 299-302, dez. 2020.

Estivesse Detroit coberta de gelo ou quente como motor de Ford - como estava hoje - o ônibus de número 33 chegava sempre exatamente às 17h12, sem falta. Era, precisamente, onze minutos de atraso, segundo o quadro público de horários que Ibrahim tinha memorizado e ajustado para a realidade. Como fazia todas as quartas e sextas-feiras às $17 \mathrm{~h} 12$, Ibrahim deixou que sua bengala guiasse suas pernas cansadas para subir os degraus do ônibus, sabendo bem que hoje era um longo tempo e um mundo de distância de sua infância, quando costumava subir as montanhas do Líbano em busca de figos frescos para a geleia de sua mãe.

\footnotetext{
1 Este texto foi publicado em língua inglesa por Alia Yunis, com o título "The Lebanon-Detroit Express" na antologia Dinarzad's children: an anthology of contemporary Arab American fiction, pela The University of Arkansas Press, em 2009.
}

$\triangle$ priscilacscampello@gmail.com

\section{thomazogomes@gmail.com}




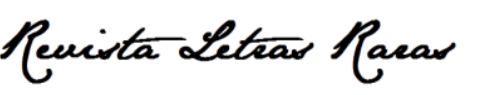

ISSN: 2317-2347 - v. 9, n. 4 (2020)

Todo o conteúdo da RLR está licenciado sob Creative Commons Atribuição 4.0 Internacional

"O trânsito tá lento hoje", disse o motorista do ônibus, com a mesma incredulidade frustrada. Falava isso todos os dias, com nevasca ou calor, como se fosse novidade. Ibrahim fez como quem dissesse - fazer o quê? - e tomou seu lugar três assentos atrás do motorista, propositalmente evitando contato visual com a jovem moça com um piercing no umbigo que havia se levantado para dar-lhe um assento de idosos, expondo sua tatuagem do símbolo da paz, localizada bem onde Ibrahim pensava que apenas mães e maridos deveriam ver.

O motorista estava, de fato, sempre certo. $O$ trânsito era tão devagar a esta hora do dia que lbrahim podia sempre olhar pela janela e ver a que filme impróprio o homem gordo na esquina da Rua 6 estava assistindo, geralmente de cueca, hoje, bebendo uma Bud Light. O cara deve estar de dieta, pensou Ibrahim, enquanto voltava sua atenção para a TV do homem. Independentemente do que as garotas más estavam fazendo na TV, elas mexiam com Ibrahim em lugares nos quais ele raramente era mexido hoje em dia, fazendo-o pensar na moça em sua vila com quem ele iria se casar, aquela com as duas longas e grossas tranças negras. A moça - qual era mesmo o seu nome? - tinha sempre quinze anos pra ele, mesmo setenta anos depois, a única imagem que sobrou dela, em sua fraca memória, era ela em frente ao espelho, chorando silenciosamente, desfazendo suas tranças apenas minutos depois de ele falar com o pai dela que não poderiam se casar. Ela nunca saberia que ele estava do lado de fora de sua casa olhando-a, sua voluptuosidade amenizada por sua virgindade. Qual fora a desculpa que ele deu para não se casar com ela? Ele não conseguia se lembrar agora - alguma coisa sobre ir para a América para construir carros mas, naquele momento, fez sentido.

Os carros moveram-se finalmente. Agora veio a casa da loira oxigenada usando seu moletom rosa choque e enrolando um baseado. Às vezes, ela se importava em pentear o cabelo, mas hoje não. Ela tinha apenas uns quarenta e poucos anos, mais ou menos a mesma idade de seu filho mais jovem. Ele sabia disso por causa do pôster do Led Zeppelin na parede dela, o mesmo que o filho de lbrahim tinha em seu quarto antes de ser mandado para a reabilitação. Ibrahim tinha culpado as pessoas naquele pôster pelos vícios do filho. A garota oxigenada deu um trago no baseado. Com seu peito de nadadora e pernas de seriema, parecia-se com a mulher de quem ele havia se divorciado cinquenta e cinco anos atrás, a garçonete que o abrigou quando ele se mudou para cá, sem emprego e com três palavras no vocabulário - sim, senhor, não. A mulher com quem ele havia se casado e então abandonado depois de dez anos, bem quando seus negócios iam de vento em popa. Chega uma hora, ele lhe disse, que você não quer mais viver com um estranho. Ele a deixou por alguém que fazia Detroit parecer um lar - por Amana, uma mulher de sua vila no Líbano que havia acabado de se divorciar de um jovem perturbado que a trouxera para a América. 


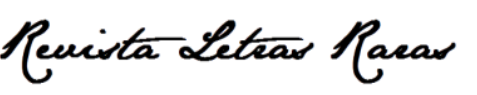

ISSN: 2317-2347 - v. 9, n. 4 (2020)

Todo o conteúdo da RLR está licenciado sob Creative Commons Atribuição 4.0 Internacional

Um avião sobrevoou o tráfego. Talvez Lina estivesse nele, sua linda filha que estava sempre indo para algum lugar, mas cuja vida não parecia ir para lugar nenhum. Talvez ela fosse jantar com ele hoje. Só um pouco de labeneh2 ${ }^{2}$, ou até mesmo pizza da Domino's. Se ela apenas comesse, ele prometeu a si mesmo, ele não Ihe lembraria de que ela queria ser a Mulher Maravilha, mas estava agora virando a Mulher Gato, uma dessas moças que vai ser encontrada morta um dia em sua casa, com quatorze gatos apinhando-se sobre ela e um passarinho faminto pulando dentro de sua gaiola. Ele lia esses tipos de coisa no jornal 0 tempo todo, e temia por sua filha.

Outro avião seguiu os rastros do primeiro. Esse avião lembrou-lhe de seus outros filhos, esses que haviam deixado Detroit para sempre, que sentiam que não tinham que vir visitar nem nos feriados. Não eram os feriados deles, ele costumava dizer, e se recusava em comprar-lhes brinquedos que seriam quebrados, de qualquer jeito, rapidamente, como se fossem descartáveis como os pratos que usava no jantar hoje em dia. Seus filhos agora passavam esses feriados com os pais dos cônjuges. Se ele soubesse que, ao vir para a América, ter filhos e não os ter seria a mesma coisa, ele nunca teria tido tantos.

Quando o ônibus parou de novo, ele pensou que a garotinha segurando a mão da mãe enquanto cruzavam a rua parecia com sua neta mais nova, especialmente porque ela estava usando luvinhas como as que Amana costurava. Mas ele deixou a possibilidade pra lá. Sua neta provavelmente estava velha demais agora para segurar a mão da mãe.

Ele estava cansado de uma vida de recordações e amaria perceber o hoje ao invés do ontem. Mas não havia nada de especial sobre o hoje. Constipação, tédio, consultas médicas, telefonemas semanais dos seus filhos que se resumiam a "como você está?" e "bem", com longos silêncios posteriores, enquanto a pessoa do outro lado da linha tentava pensar em algo para dizer para seu pai que não iria enfurecê-lo, sem perceber que Ibrahim não tinha mais raiva, apenas solidão, uma dor por eles que o dominava durante suas crises noturnas de insônia.

A única coisa que o fazia sorrir era Amana, e era uma terrível pena que ele não tinha o mesmo efeito sobre ela. Quando o tráfego ficou mais lento na Warren com Schaeffer uma hora atrás, ele a viu mancando ao sair do consultório do médico com a mesma bengala que ela fez pra si mesma, do mesmo jeito que via seu avô, o melhor entalhador da vila, fazer tantas vezes antes. Seu cabelo roxo - ela nunca sabia como pintá-lo, sempre enxaguando cedo demais ou deixando a tinta por tempo demais - ainda fluía como quando se casaram, cinquenta e cinco anos atrás e como fazia dez anos depois, quando ela se divorciou dele e dividiram as seis crianças, duas hipotecas e o pagamento do Cadillac entre eles, meio a meio. Tudo igual. Ela sempre fora justa, e ele demorou demais a perceber.

\footnotetext{
2 Labeneh pode ser traduzido como coalhada seca ou iogurte grego. 0 termo em árabe será mantido como no texto original.
} 


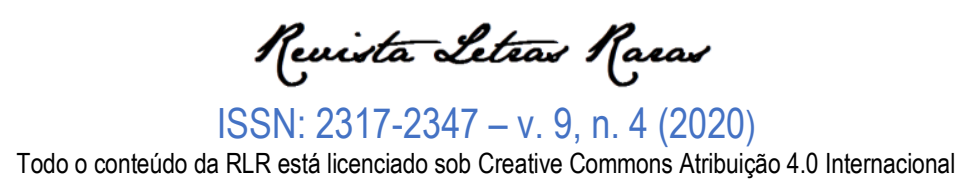

Isso não importa mais, agora. A saída para o aeroporto finalmente chegou. Aqui, ele esperaria pelo voo 247 da KLM de Amsterdã, como fazia todas as quartas e sextas-feiras. Ele esperaria os passageiros saírem da alfândega. A maioria deles seria de árabes, vinda do Líbano e da Jordânia, fazendo conexão em Amsterdã. Não eram seus parentes, mas enquanto choravam e abraçavam as pessoas que os esperavam, o som dos jantares de sua infância estaria em seus cumprimentos hiperbólicos, e o cheiro das festas de sua mãe estaria no perfume forte das velhinhas bem vestidas demais e no suor dos jovens que, por algum motivo, não acreditavam em desodorante, mas rapidamente cediam a outras coisas ocidentais como Marlboros e Eminem. Em suas volumosas malas, amarradas com cordas para não explodirem, Ibrahim imaginou os presentes de baklava ${ }^{3}$ caseira, cuidadosamente colocados por entre os casacos e jaquetas que eles precisariam aqui.

Ibrahim não precisou de seu "aparelho auditivo", como o chamava, para ouvir seus ossos rangerem quando puxou a corda para o ônibus parar. Era maio, o que significava que, se estivesse com sorte, sentiria o cheiro de jasmim com as chegadas, eles estariam florescendo no Líbano agora. Era em maio, não era, que eles floresciam? Ou em maio era a vez das madressilvas? Fazia tanto tempo.

O jovem motorista do ônibus piscou para ele, como fazia todas as tardes, "Salam-alakum, irmão", ele disse.

"Wa-alakum-a-salam, filho", disse Ibrahim, não querendo atrapalhar a tentativa diária de multiculturalismo do motorista dizendo para ele que, em sua vila, as pessoas não se cumprimentavam com aquela expressão exceto na mesquita, um lugar aonde Amana ainda ia uma vez por semana, mas no qual ele nunca havia pisado.

"A gente se vê amanhã, cara", despediu-se Ibrahim.

"Pode crer, cara", o motorista sorriu, não querendo desapontar a tentativa diária de multiculturalismo do velho explicando que homens negros, acima dos cinquenta, nunca falavam "cara".

Ibrahim olhou para seu relógio. Ele mancou um pouco mais rápido. Droga de tráfego americano. Bem, talvez o avião estivesse atrasado também. Ou nós morremos, pensou, ou temos a chance de ficarmos velhos em algum lugar.

\section{Referência}

YUNIS, A. "The Lebanon-Detroit Express". In: KALDAS, Pauline; MATTAWA, Khalded. Dinarzad's children: an anthology of contemporary Arab American fiction. 2. ed. Fayetteville: The University of Arkansas Press. 2009. p. 375-378. ISBN: 1557289123.

${ }_{3}^{3}$ Baklava é um doce típico, parecido com um pastel, recheado de doce de nozes trituradas e embebido em xarope ou mel. 